\section{Fertilizer Concentration Affects Growth and Flowering of Subirrigated Petunias and Begonias}

\author{
Erin C. James and Marc W. van Iersel ${ }^{1}$ \\ Department of Horticulture, Georgia Station, University of Georgia, 1109 \\ Experiment Street, Griffin, GA 30223-1797
}

Additional index words. ebb and flow, $\mathrm{pH}$, electrical conductivity, nutrition, Petunia

$\times$ hybrida, Begonia $\times$ semperflorens, leachate

\begin{abstract}
Nitrate pollution and water conservation are two of the most important environmental concerns for greenhouse growers. Closed irrigation systems, such as ebb and flow, can minimize these problems. The objective of this study was to determine optimal fertilizer concentrations for petunia (Petunia Xhybrida Hort. Vilm-Andr.) and begonia (Begonia $\times$ semperflorens-cultorum Hort.) grown with ebb-and-flow irrigation. 'Ambassador Scarlet' begonia and 'Dreams Mix' petunia were grown as bedding plants in three soilless media. Plants were fertilized with solutions of a $20 \mathrm{~N}-4.4 \mathrm{P}-16.6 \mathrm{~K}$ water-soluble fertilizer with electrical conductivities (EC) of $0.15,0.6,1.2,1.8,2.4$, or $3.0 \mathrm{dS} \cdot \mathrm{m}^{-1}$. Maximum growth occurred with a fertilizer EC of $2.2 \mathrm{dS} \cdot \mathrm{m}^{-1}$ for petunia and $1.6 \mathrm{dS} \cdot \mathrm{m}^{-1}$ for begonia. Petunia growth was best in the medium with the highest porosity (Metro-Mix 220), but choice of medium had little effect on begonia growth. Leachate $\mathrm{EC}$ and $\mathrm{pH}$ were determined throughout the experiment, using the pour-through method. Leachate EC rose with increasing fertilizer concentration, and increased over time. The $\mathrm{pH}$ of the leachate decreased with increasing fertilizer concentration and dropped 0.5 to 1 unit over the course of the experiment with the higher fertilizer concentrations $\left(\geq 0.6 \mathrm{dS} \cdot \mathrm{m}^{-1}\right)$. Plant growth was not very sensitive to leachate EC. Begonia and petunia grew well when the EC at the end of the production cycle was between 1.7 to 6.1 and 2.1 and $5.4 \mathrm{dS} \cdot \mathrm{m}^{-1}$, respectively.
\end{abstract}

Fertilizer and pesticide runoff from greenhouses can contaminate ground and surface water. Nitrate runoff is currently one of the largest pollution problems for the floriculture industry. The EPA estimates that nitrates are present $\left(>0.15 \mathrm{mg} \cdot \mathrm{L}^{-1}\right)$ in over one-half of the wells in the United States that are used for drinking water (National Pesticide Survey, 1990). The continued increase in population and demand for water in the southeastern United States are also concerns because of limited water resources. The amount of water consumed and the amount of fertilizer allowed in runoff from greenhouse operations will probably be regulated in the future (Poole and Conover, 1992). Alternative irrigation systems that allow no runoff into the environment, such as ebb and flow, are widely used to reduce

Received for publication 19 Mar. 1999. Accepted for publication 19 June 2000. This paper is a portion of a thesis submitted by E.J. in partial fulfillment of the MS degree requirements at the Univ. of Georgia. Mention of brand names is for informational purposes only and does not imply its approval to the exclusion of other products that may also be suitable. We thank Sunbelt Greenhouses (Douglas, Ga.) for the donation of plant material, The Scotts Co. (Marysville, Ohio) for donation of the soilless media, and Jerry Davis for his statistical advice. The cost of publishing this paper was defrayed in part by the payment of page charges. Under postal regulations, this paper therefore must be hereby marked advertisement solely to indicate this fact

${ }^{1}$ To whom requests for reprints should be addressed. E-mail address:mvanier@gaes.griffin.peachnet.edu practices. Several experiments have been conducted using begonias in soilless media. Chase and Poole (1987), Gislerød and Mortensen (1990), and Witte and Sheenan (1974) all found that there is an optimal fertilizer concentration for growth. Similarly, Frett et al. (1985) compared growth of petunias fertilized with $0,100,200$, or $400 \mathrm{mg} \cdot \mathrm{L}^{-1} \mathrm{~N}$; dry weight, branch length, and flowering were greatest with $200 \mathrm{mg} \cdot \mathrm{L}^{-1} \mathrm{~N}$. None of these experiments was conducted using closed subirrigation systems. The only known study on fertilizer rates with subirrigated begonias was conducted by Lemaire et al. (1995), who determined the effect of fertilizer concentration on begonia growth. They found that shoot weight was maximized at a fertilizer EC of 1.36 to 1.5 $\mathrm{dS} \cdot \mathrm{m}^{-1}$. However, they did not quantify the effects of fertilizer concentration on growing medium EC and $\mathrm{pH}$. These parameters may be better indicators of whether medium fertility levels are adequate for optimal plant growth, because the optimal fertilizer concentration depends on the water use efficiency of the plants (Bugbee, 1995), and thus on environmental conditions.

Research on fertilization in ebb-and-flow systems is limited. Kent and Reed (1996), using concentrations ranging from 0 to 450 $\mathrm{mg} \cdot \mathrm{L}^{-1} \mathrm{~N}$ in the fertigation solution, found that shoot dry weight of New Guinea impatiens (Impatiens Xhawkeri Bull.) and peace lily (Spathiphyllum Schott) was highest when grown with $120-150 \mathrm{mg} \cdot \mathrm{L}^{-1} \mathrm{~N}$. Optimal nitrogen concentration in the fertilizer solution for subirrigated pansies (Viola $\times$ wittrockiana Gam.) was 150 to $250 \mathrm{mg} \cdot \mathrm{L}^{-1}$, while the optimal EC of the leachate (collected using the pour-through method) was 1.5 to $4 \mathrm{dS} \cdot \mathrm{m}^{-1}$ (van Iersel, 1999).

Information is also lacking on the effect of the growing medium on plant growth in subirrigation systems. De Kreij and Straver (1988) found maximum Codiaeum growth in an ebb-and-flow system in media with the highest volumetric air content. Blom and Piott (1992) obtained better growth of chrysanthemum [Dendranthema $\times$ grandiflorum (Ramat.) Kitamura] in compacted peat than in noncompacted peat. Argo and Biernbaum (1994) compared Easter lily (Lilium longiflorum Thunb.) grown with ebb-and-flow irrigation and five commercially available, peat-based media, and found that the waterholding capacity of the media had more effect than the chemical properties. Although the growing medium can affect the growth of subirrigated plants, no studies have compared commercially available soilless media for use with bedding plants in subirrigation systems. Since coconut (Cocos nucifera L.) coir has been considered as a possible replacement for peat in soilless media (Evans and Iles, 1997; Stamps and Evans, 1997), we wanted to determine its suitability for use in subirrigation systems.

The objectives of this experiment were to: 1) determine the effects of different fertilizer concentrations on the growth of petunias and begonias throughout the growing period; 2) quantify how the composition of soilless me- 
dia affects growth; and 3) establish the optimal range for the leachate $\mathrm{EC}$ and $\mathrm{pH}$ of the growing media.

\section{Materials and Methods}

Treatments. Plug seedlings (288 cells/flat) of 'Dreams Mix' petunia and 'Ambassador Scarlet' begonia were obtained from a commercial producer and transplanted into $10-\mathrm{cm}$ square plastic pots $(510 \mathrm{~mL})$ on 21 and 23 Apr. 1997, respectively. The pots were filled with one of three soilless media, MetroMix 220 (MM220), MetroMix 366 ScottsCoir (MM366C), or MetroMix 500 (MM500) (Scotts Co., Marysville, Ohio). Seedlings were watered in thoroughly after transplanting. All plants were then placed on $2.4 \times 1.2 \mathrm{~m}^{2}$ $(1 \times$ w) ebb-and-flow benches (MidWest GroMaster, St. Charles, Ill.), and fertigated with a $20 \mathrm{~N}-4.4 \mathrm{P}-16.6 \mathrm{~K}$ water-soluble fertilizer solution (Peter's 20-10-20 Peat-Lite Special, Scotts Co.) with an EC of 0.15, 0.6, 1.2, $1.8,2.4$, or $3.0 \mathrm{dS} \cdot \mathrm{m}^{-1}$. This provided $\approx 0,70$, $165,255,350$, or $440 \mathrm{mg} \cdot \mathrm{L}^{-1} \mathrm{~N}\left(60 \% \mathrm{NO}_{3}{ }^{-}\right.$and $\left.40 \% \mathrm{NH}_{4}^{+}\right), 0,15,35,55,75$, or $95 \mathrm{mg} \cdot \mathrm{L}^{-1} \mathrm{P}$ and $0,60,135,210,290$, or $365 \mathrm{mg} \cdot \mathrm{L}^{-1} \mathrm{~K}$. The tap water used to mix the fertilizer solutions was low in $\mathrm{Ca}^{2+}\left(10.5 \mathrm{mg} \cdot \mathrm{L}^{-1}\right)$ and $\mathrm{Mg}^{2+}(1.7$ $\left.\mathrm{mg} \cdot \mathrm{L}^{-1}\right)$, had a low EC $\left(0.15 \mathrm{dS} \cdot \mathrm{m}^{-1}\right)$ and total alkalinity $\left(50 \mathrm{mg} \cdot \mathrm{L}^{-1} \mathrm{CaCO}_{3}\right)$, and a $\mathrm{pH}$ of 6.4 and therefore was of excellent quality for greenhouse irrigation (Bunt, 1988). Plants were irrigated as needed, ranging from twice a week at the beginning to daily at the end of the experiment.

The growing media varied in their chemical and physical properties. Initial nutrient concentrations, $\mathrm{EC}$, and $\mathrm{pH}$ were determined using the saturated medium extraction method (Warncke, 1986) and the physical properties were determined with the NCSU porometer method (Fonteno and Bilderback, 1993). They all had similar starter charges of $\mathrm{N}$ and $\mathrm{P}$, but $\mathrm{K}$ varied widely (Table 1 ). The media also differed in their ratios of peat moss, pine bark, vermiculite, perlite, and coconut coir. MM500 had the highest percentage of pine bark, and was lowest of the three in water-holding capacity and total porosity. MM220 had significantly more vermiculite than MM366C and MM500, and was highest in total porosity and water-holding capacity. MM366C contained

Measurements. Shoot dry weight, height, width, and number of flowers were measured weekly for petunias and biweekly for begonias on four plants per experimental unit. Height was determined as the distance from coconut coir instead of peat moss.

the media surface to the highest point of the plant. Begonia width was not measured at 1 week after transplanting. Leachate $\mathrm{EC}$ and $\mathrm{pH}$ readings were taken periodically throughout the experiment using the pour-through method (Wright, 1986) on two plants per experimental unit. About $150 \mathrm{~mL}$ of tap water was applied to the surface of the medium in the container, 1 to $3 \mathrm{~h}$ after an irrigation event. The first 75 $\mathrm{mL}$ of leachate was collected for evaluation. Leachate $\mathrm{pH}$ and $\mathrm{EC}$ were measured with a Corning M90 portable meter (Corning, Corning, N.Y.). Although begonias and petunias reached a saleable size at 5 and 3 weeks after transplanting, respectively, measurements were collected for 2 more weeks. This allowed the quantification of more long-term treatment effects.

At the end of the experiment, total $\mathrm{N}$ of dried plant shoots (leaves, stems, and flowers) was determined with a LECO CNS 2000 (LECO Corp., St. Joseph, Mich.) (Mills and Jones, 1996). Total $\mathrm{P}$ and $\mathrm{K}$ were determined by dry ashing and inductively coupled plasma spectrometry, using a Jarrell-Ash ICAP 9000 (Thermo Jarrell Ash Corp., Franklin, Mass.) (Jones and Case, 1990).

Experimental design. This was a split-plot experiment with two replications and repeated measures. Fertilizer EC level was the main plot and growing medium was the split, i.e., every bench received one of six fertilizer concentrations, while each bench contained plants grown in all three media. The experimental unit was a group of 20 petunia or 16 begonia plants. Growth data were analyzed by sampling time, using analysis of variance and linear regression. When there were no significant interactions between growing medium and fertilizer concentrations, growth parameters were averaged over growing media before testing for significant fertilizer effects. The regression equations were used to determine which EC would be expected to result in maximum growth. For practical purposes, determining an EC range in which growth is acceptable is more important than determining the exact EC at which growth is maximal. For this study, acceptable growth was defined as at least $90 \%$ of the maximal growth. The acceptable EC range also was determined from the regression equations.

The effects of fertilizer EC on leachate EC were analyzed separately for each sampling time using linear regression. Significant differences in EC of leachates were determined with tests for homogeneity of slopes and intercepts. Changes in leachate $\mathrm{pH}$ over time also were analyzed by linear regression.

Table 1. Chemical and physical properties of the three soilless growing media used to grow petunias and begonias. Chemical properties were determined using the saturated medium extraction method and the physical properties were determined with the NCSU porometer method.

\begin{tabular}{|c|c|c|c|c|c|c|c|c|}
\hline \multirow[b]{2}{*}{ Medium } & \multirow{2}{*}{$\begin{array}{c}\mathrm{EC} \\
\mathrm{dS} \cdot \mathrm{m}^{-1} \\
\end{array}$} & \multirow[b]{2}{*}{$\mathrm{pH}$} & $\mathrm{N}$ & $\mathrm{P}$ & K & $\begin{array}{c}\text { Total } \\
\text { porosity }\end{array}$ & $\begin{array}{c}\text { Air } \\
\text { space }\end{array}$ & $\begin{array}{c}\text { Container } \\
\text { capacity }\end{array}$ \\
\hline & & & \multicolumn{3}{|c|}{$\left(\mathrm{mg} \cdot \mathrm{L}^{-1}\right)$} & \multicolumn{3}{|c|}{$(\%)$} \\
\hline$\overline{\text { MM220 }}$ & 2.00 & 6.2 & 64 & 4.8 & 89 & 87.1 & 6.6 & 80.4 \\
\hline MM366Coir & 2.60 & 5.4 & 76 & 3.4 & 345 & 82.1 & 5.3 & 76.8 \\
\hline MM500 & 1.40 & 5.6 & 63 & 4.1 & 154 & 80.1 & 6.5 & 73.6 \\
\hline
\end{tabular}

\section{Results and Discussion}

Throughout the experiment, begonia and petunia showed similar trends in the shoot dry weight (Figs. 1A and 2A). Regression analysis indicated a significant linear effect of fertilizer concentration on begonia shoot dry weight 3 weeks after transplanting (WAT). At 5 and 7 WAT, quadratic effects were significant. At 7 WAT, dry weight of begonia was maximal at a fertilizer solution EC of $1.7 \mathrm{dS} \cdot \mathrm{m}^{-1}$, and acceptable from 1.0 to $2.4 \mathrm{dS} \cdot \mathrm{m}^{-1}$ (Fig. 1A). This is comparable to results reported by Gislerød and Mortensen (1990), who found that dry weight of begonia was higher when plants were fertigated at $2 \mathrm{dS} \cdot \mathrm{m}^{-1}$ than at 1 or $4 \mathrm{dS} \cdot \mathrm{m}^{-1}$. Dole et al. (1994) found that poinsettia (Euphorbia pulcherrima Willd. Ex. Klotzsch) grown with ebb and flow with $20 \mathrm{~N}-4.4 \mathrm{P}-16.6 \mathrm{~K}$ grew most rapidly at $175 \mathrm{mg} \cdot \mathrm{L}^{-1} \mathrm{~N}$, and growth declined at higher fertilization rates, just as in begonia. The shoot dry weight of New Guinea impatiens also declined with $\mathrm{N}$ concentrations above $150 \mathrm{mg} \cdot \mathrm{L}^{-1}$ (Kent and Reed, 1996).

Changes in begonia shoot height and width were similar (Fig. 1, B and C). At 3 WAT, height was greatest for plants at an EC of $2.2 \mathrm{dS} \cdot \mathrm{m}^{-1}$. At 5 and $7 \mathrm{WAT}$, plant height was maximal in plants grown with fertilizer at 1.4 and $1.3 \mathrm{dS} \cdot \mathrm{m}^{-1}$, respectively. Maximum width occurred at $1.6 \mathrm{dS} \cdot \mathrm{m}^{-1}$. Since the ECs for maximal dry weight, plant height, and width of begonia were similar, managing the fertilizer concentration to produce compact begonia plants does not appear to be possible without sacrificing growth.

Petunia growth was affected by fertilizer concentration as early as the first week of growth (Fig. 2A). At 1, 3, 4, and 5 WAT, the relationship between fertilizer EC and dry weight was quadratic, with maximum dry weight at $\approx 2.3 \mathrm{dS} \cdot \mathrm{m}^{-1}\left(330 \mathrm{mg} \cdot \mathrm{L}^{-1} \mathrm{~N}\right)$. At 5 weeks after transplanting, shoot dry weight was acceptable with a fertilizer EC ranging from 1.4 to $2.9 \mathrm{dS} \cdot \mathrm{m}^{-1}$. Frett et al. (1985) also found a reduction in shoot dry weight of petunia with high $\mathrm{N}$ concentration $\left(400 \mathrm{mg} \cdot \mathrm{L}^{-1}\right)$ in the fertilizer.

Height of petunia was maximized at a slightly lower EC $\left(1.8 \mathrm{dS} \cdot \mathrm{m}^{-1}\right)$ than was shoot dry weight (Fig. 2B). Width of petunias was linearly correlated with fertilizer EC at 2 WAT and quadratically at 3,4 , and 5 WAT. Maximum width (Fig. 2C) occurred at similar EC levels as maximum dry weight $\left(2.35 \mathrm{dS} \cdot \mathrm{m}^{-1}\right.$ at $3 \mathrm{WAT}$ and $2.0 \mathrm{dS} \cdot \mathrm{m}^{-1}$ at $5 \mathrm{WAT}$ ). Generally, maximum growth rate (weight, height, width) occurred at higher fertilizer EC for petunia than for begonia (Figs. 1 and 2).

Begonia flowering at 3, 5, and 7 WAT responded quadratically to fertilizer concentration (Fig. 1D). Plants grown with fertilizer at EC $1.9,1.7$, and $1.6 \mathrm{dS} \cdot \mathrm{m}^{-1}$ produced the maximum number of inflorescences at 3,5 , and 7 WAT, respectively. At 7 WAT, the number of inflorescences was $\geq 10 \%$ less in plants grown with a fertilizer EC $<0.85$ or $>2.3 \mathrm{dS} \cdot \mathrm{m}^{-1}$, than in those grown with an EC of $1.6 \mathrm{dS} \cdot \mathrm{m}^{-1}$. These results differ from those of Gislerød and Mortensen (1990), who found no decline in flowering of begonia at their highest 


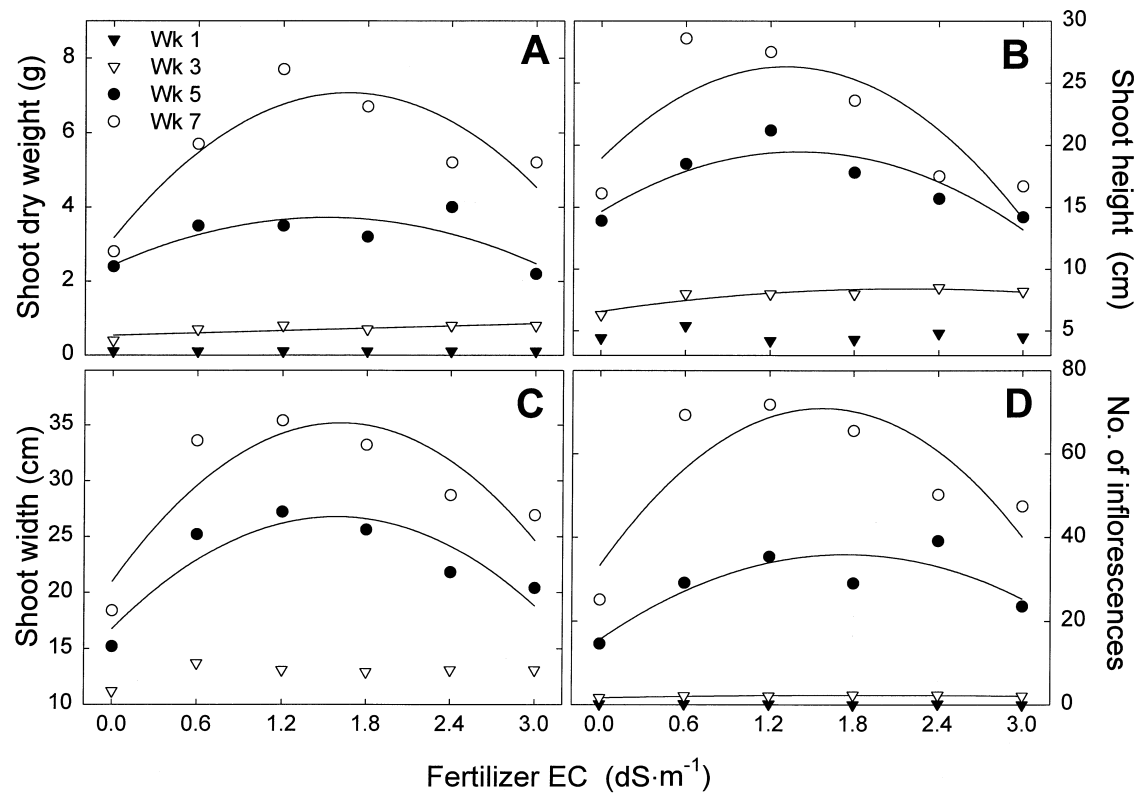

Fig. 1. The effect of fertilizer EC on the dry weight, height, width, and number of inflorescences of begonias Plants were fertigated with $20 \mathrm{~N}-4.4 \mathrm{P}-16.6 \mathrm{~K}$ at $0,0.6,1.2,1.8,2.4$, or $3.0 \mathrm{dS} \cdot \mathrm{m}^{-1}$ with every irrigation event for 5 weeks. Each point represents the mean of 24 observations, pooled over three media types. Where linear or quadratic effects were significant $(P \leq 0.05)$, lines indicate the calculated regression, otherwise no lines are shown.

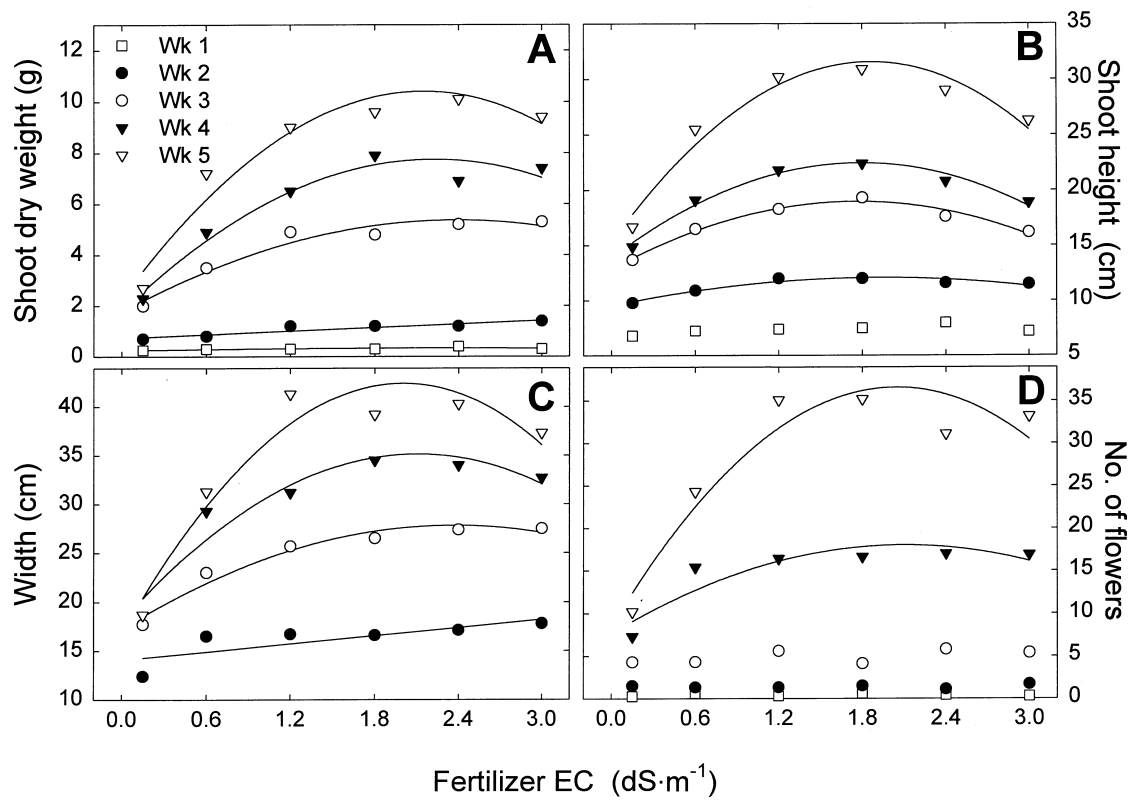

Fig. 2. The effect of fertilizer EC on the dry weight, height, width, and number of flowers of petunias. Plants were fertigated with $20 \mathrm{~N}-4.4 \mathrm{P}-16.6 \mathrm{~K}$ at $0,0.6,1.2,1.8,2.4$, or $3.0 \mathrm{dS} \cdot \mathrm{m}^{-1}$ with every irrigation event for 7 weeks. Each point represents the mean of 24 observations, pooled over three media types. Where linear or quadratic effects were significant $(P \leq 0.05)$, lines indicate the calculated regression, otherwise no lines are shown.

fertilizer rate $\left(350 \mathrm{mg} \cdot \mathrm{L}^{-1} \mathrm{~N}\right)$. Petunia flowering also was quadratically related to fertilizer concentration (Fig. 2D), but the maximum number of flowers occurred at a higher fertilizer EC $\left(2.1 \mathrm{dS} \cdot \mathrm{m}^{-1}\right)$ than in begonia. At $5 \mathrm{WAT}$, a $10 \%$ or greater reduction in flowering of petunia occurred at an $\mathrm{EC}<1.3 \mathrm{dS} \cdot \mathrm{m}^{-1}$ or $>2.8$ $\mathrm{dS} \cdot \mathrm{m}^{-1}$. Frett et al. (1985) reported less flowering of petunias grown with 400 than with $200 \mathrm{mg} \cdot \mathrm{L}^{-1} \mathrm{~N}$. greatest width at $3 \mathrm{WAT}$, but plants grown in MM366C or MM500 had greatest width at 5 and 7 WAT. Width of petunia was greater in MM220 than in MM366C or MM500 at 3, 4, and 5 WAT.

Tissue $\mathrm{N}$ level was not affected by fertilizer concentration in either species (Table 2). Tissue levels of $\mathrm{N}$ were adequate in both species in all fertilizer concentrations, according to the guidelines of Mills and Jones (1996). This lack of fertilizer effect on tissue $\mathrm{N}$ levels was also seen in production of subirrigated pansies (van Iersel, 1999).

Although the correlation between the concentration of the fertilizer and the levels of $\mathrm{P}$ in the petunias was nonsignificant, that in begonias was significant (Table 2). With the rise of the fertilizer EC from 0.15 to $0.6 \mathrm{dS} \cdot \mathrm{m}^{-1}$ (an addition of $\approx 15 \mathrm{mg} \cdot \mathrm{L}^{-1} \mathrm{P}$ in the fertigation solution), begonia tissue $\mathrm{P}$ increased $112 \%$. At the highest fertility rate of $3.0 \mathrm{dS} \cdot \mathrm{m}^{-1}(95$ $\left.\mathrm{mg} \cdot \mathrm{L}^{-1} \mathrm{P}\right)$, the begonia tissue $\mathrm{P}$ level was $185 \%$ higher $\left(9.7 \mathrm{mg} \cdot \mathrm{g}^{-1}\right)$ than at $0.15 \mathrm{dS} \cdot \mathrm{m}^{-1}$. This is substantially more than the upper level of the sufficiency range $\left(7.5 \mathrm{mg} \cdot \mathrm{g}^{-1}\right)$ reported by Mills and Jones (1996), suggesting luxury consumption. Luxury consumption of $\mathrm{P}$ also occurs in petunia plugs (van Iersel et al., 1998).

Tissue K level of both species increased with increasing fertilizer EC and $\mathrm{K}$ concentration in the fertilizer solution (Table 2). However, the rates of increase differed for the two species. When the concentration of $\mathrm{K}$ in the fertilizer solution was increased from 0 to $365 \mathrm{mg} \cdot \mathrm{L}^{-1}\left(0.15\right.$ to $\left.3 \mathrm{dS} \cdot \mathrm{m}^{-1}\right)$, the level of $\mathrm{K}$ in petunia tissue increased only $10 \%$, while that in begonia tissue increased $188 \%$. Tissue $\mathrm{K}$ levels for petunias and begonias grown in all fertilizer concentrations were within their respective sufficiency ranges (Mills and Jones, 1996).

Since fertilizer EC had similar effects on the $\mathrm{pH}$ and $\mathrm{EC}$ of the leachate of both species, only results from the begonia leachate are presented (Figs. 3 and 4). As expected, the leachate EC increased with increasing fertilizer concentration (Fig. 3, Table 3). The leachate EC increased rapidly in begonias fertigated at $3.0 \mathrm{dS} \cdot \mathrm{m}^{-1}$ (Fig. 3). At $3 \mathrm{WAT}$, the EC of the leachate was 4.7, 4.2, and 3.4 $\mathrm{dS} \cdot \mathrm{m}^{-1}$ for begonias grown in MM220, MM366C, and MM500, respectively. By the end of the growing cycle, the highest leachate EC (averaged over the three media) was 8.3 $\mathrm{dS} \cdot \mathrm{m}^{-1}$ in begonias (7 WAT) and $5.5 \mathrm{dS} \cdot \mathrm{m}^{-1}$ in petunias ( $5 \mathrm{WAT}$ ). This is above the recommended range of 3.0 to $5.0 \mathrm{dS} \cdot \mathrm{m}^{-1}$ for leachate EC levels when using the pour-through method (Lang, 1996). Poinsettias have also been grown with a higher than recommended growing medium $\mathrm{EC}\left(>3 \mathrm{dS} \cdot \mathrm{m}^{-1}\right.$, using a $1: 2$ dilution method), with no negative effects (Morvant et al., 1998).

The leachate EC was similar and low $\left(\approx 0.3 \mathrm{dS} \cdot \mathrm{m}^{-1}\right)$ in all three media subirrigated with tap water. This suggests that the starter fertilizer had been taken up by the plants or was leached out when the plants were watered in after transplanting. At all times and for all three media, there was a highly signifi- 
Table 2. The effects of fertilizer EC on shoot tissue $\mathrm{N}, \mathrm{P}$, and $\mathrm{K}$ levels of subirrigated petunias and begonias, sampled at 5 and $7 \mathrm{WAT}$, respectively. Regression equations: petunia $\mathrm{K}=53.8$ $+1.73 \cdot \mathrm{EC}, P=0.04$; begonia $\mathrm{P}=3.84+$ $4.05 \cdot \mathrm{EC}-0.752 \cdot \mathrm{EC}^{2}, P \leq 0.0001$; begonia $\mathrm{K}=$ $26.6+23.5 \cdot \mathrm{EC}-4.87 \cdot \mathrm{EC}^{2}, P \leq 0.0001$.

\begin{tabular}{|c|c|c|c|c|}
\hline \multirow{3}{*}{ Species } & \multirow{2}{*}{$\frac{\text { Fertilizer EC }}{\left(\mathrm{dS} \cdot \mathrm{m}^{-1}\right)}$} & $\mathrm{N}$ & $\mathrm{P}$ & $\mathrm{K}$ \\
\hline & & \multicolumn{3}{|c|}{$\left(\mathrm{mg} \cdot \mathrm{g}^{-1}\right)$} \\
\hline & 0.15 & 52.8 & 7.0 & 53.8 \\
\hline \multirow{6}{*}{ Petunia } & 0.6 & 55.5 & 8.1 & 55.7 \\
\hline & 1.2 & 53.7 & 9.4 & 55.6 \\
\hline & 1.8 & 53.7 & 6.6 & 56.4 \\
\hline & 2.4 & 57.5 & 8.1 & 58.1 \\
\hline & 3.0 & 53.5 & 10.5 & 59.3 \\
\hline & Significance & $\mathrm{NS}^{*}$ & NS & $\mathrm{L}$ \\
\hline \multirow[t]{7}{*}{ Begonia } & 0.15 & 54.3 & 3.4 & 25.4 \\
\hline & 0.6 & 51.8 & 7.2 & 45.0 \\
\hline & 1.2 & 53.8 & 8.1 & 49.8 \\
\hline & 1.8 & 53.9 & 8.1 & 50.9 \\
\hline & 2.4 & 53.4 & 8.5 & 51.0 \\
\hline & 3.0 & 54.4 & 9.7 & 55.6 \\
\hline & Significance & NS & Q & Q \\
\hline
\end{tabular}

"Nonsignificant (NS), linear (L), or quadratic (Q); $P \leq 0.05$.

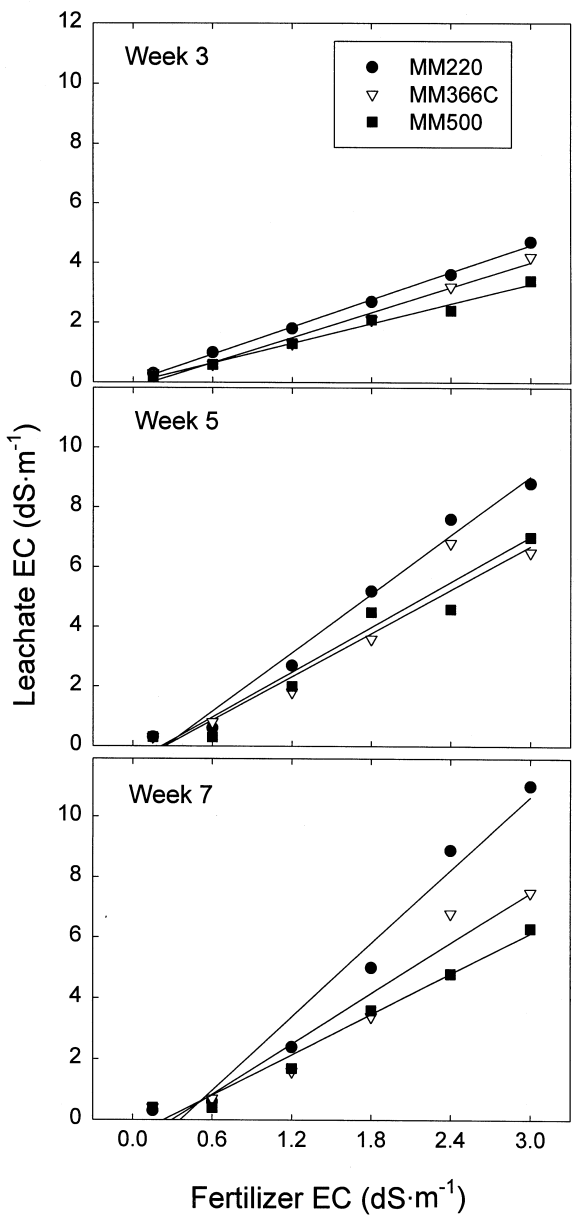

Fig. 3. The effect of fertilizer EC on the leachate EC of three different soilless media of begonias at 3 , 5 , and 7 weeks after transplanting $(n=4)$. Regression coefficients and statistical analyses are presented in Table 3. cant $(P<0.0001)$ linear correlation between fertilizerEC and begonia leachateEC. Leachate EC increased more rapidly with increasing fertilizer EC in MM220 than in MM366C (at 5 and 7 WAT) and MM500 (at 3, 5, and 7 WAT) (Fig. 3, Table 3). The higher cation exchange capacity of vermiculite than of pine bark (Bunt, 1988) may have helped MM220 to retain fertilizer salts. This may explain why the leachate from plants grown in MM220 had the highest EC values. Plant growth was not very sensitive to leachate EC. Begonia growth was reduced by $<10 \%$ (as compared to the maximum growth) in treatments with a leachate EC of 2.1 to $6.3 \mathrm{dS} \cdot \mathrm{m}^{-1}$ at the end of the experiment (averaged over all three media). For petunia, this range was 2.3 to $5.2 \mathrm{dS} \cdot \mathrm{m}^{-1}$. This does not necessarily mean that begonia and petunia can tolerate a leachate EC of 6.1 and $5.4 \mathrm{dS} \cdot \mathrm{m}^{-1}$ throughout the entire production period, but rather that they can withstand it for a short period.

Leachate $\mathrm{pH}$ did not differ significantly among media, and data from all media were averaged for further analysis. Leachate $\mathrm{pH}$ was negatively correlated with fertilizer EC, as expected with the potential acidity of the fertilizer $\left(199 \mathrm{~g} \cdot \mathrm{kg}^{-1} \mathrm{CaCO}_{3}\right)$. Begonia leachate $\mathrm{pH}$ was correlated linearly with fertilizer EC at 3 WAT, and quadratically at 5 and 7 WAT (Fig. 4). Leachate $\mathrm{pH}$ decreased between 3 and 5 WAT in all fertilized treatments, but did not decrease further from 5 to $7 \mathrm{WAT}$. The leachate $\mathrm{pH}$ of the unfertilized plants $\left(0.15 \mathrm{dS} \cdot \mathrm{m}^{-1}\right)$ remained constant throughout the experiment. Leachate $\mathrm{pH}$ ranged from 5.1 to 6.8 for petunias (not shown), and 4.6 to 7.0 for begonias.
The recommended $\mathrm{pH}$ range to prevent micronutrient deficiencies is 5.5 to 6.5 (Lang, 1996). Although leachate $\mathrm{pH}$ in some of the treatments became lower than recommended, this had no obvious negative effect on the plants. There were no visual symptoms of nutrient deficiencies, and $\mathrm{P}$ - and $\mathrm{K}$-concentrations of the shoots were increased at high fertilizer EC, while $\mathrm{N}$-concentration was unaffected (Table 2).

\section{Conclusions}

Good quality, subirrigated petunias and begonias can be grown with a range of fertilizer concentrations and in different growing media. Final dry weight was maximized when begonias and petunias were grown with a fertilizer solution with an EC of 1.7 and 2.2 $\mathrm{dS} \cdot \mathrm{m}^{-1}$, respectively. These fertilizer EC levels resulted in a leachate EC of $3.8 \mathrm{dS} \cdot \mathrm{m}^{-1}$ for both begonia and petunia at the end of the growing period (averaged over all three media). There were some effects from the different growing media, but they were small compared with the effects of fertilizer concentration. Petunia grew fastest in MM220, but growing medium effects on begonia were inconsistent. An increase of fertilizer EC from 0.15 to $0.6 \mathrm{dS} \cdot \mathrm{m}^{-1}$ increased tissue $\mathrm{P}$ and $\mathrm{K}$ levels in begonias and $\mathrm{K}$ level in petunias, but further increases in fertilizer EC had little effect. Fertilizer EC did not affect tissue levels of $\mathrm{N}$. The EC and $\mathrm{pH}$ of the media were highly affected by the fertilizer EC. Over the course of the growing period, EC of the leachate increased and $\mathrm{pH}$ dropped.

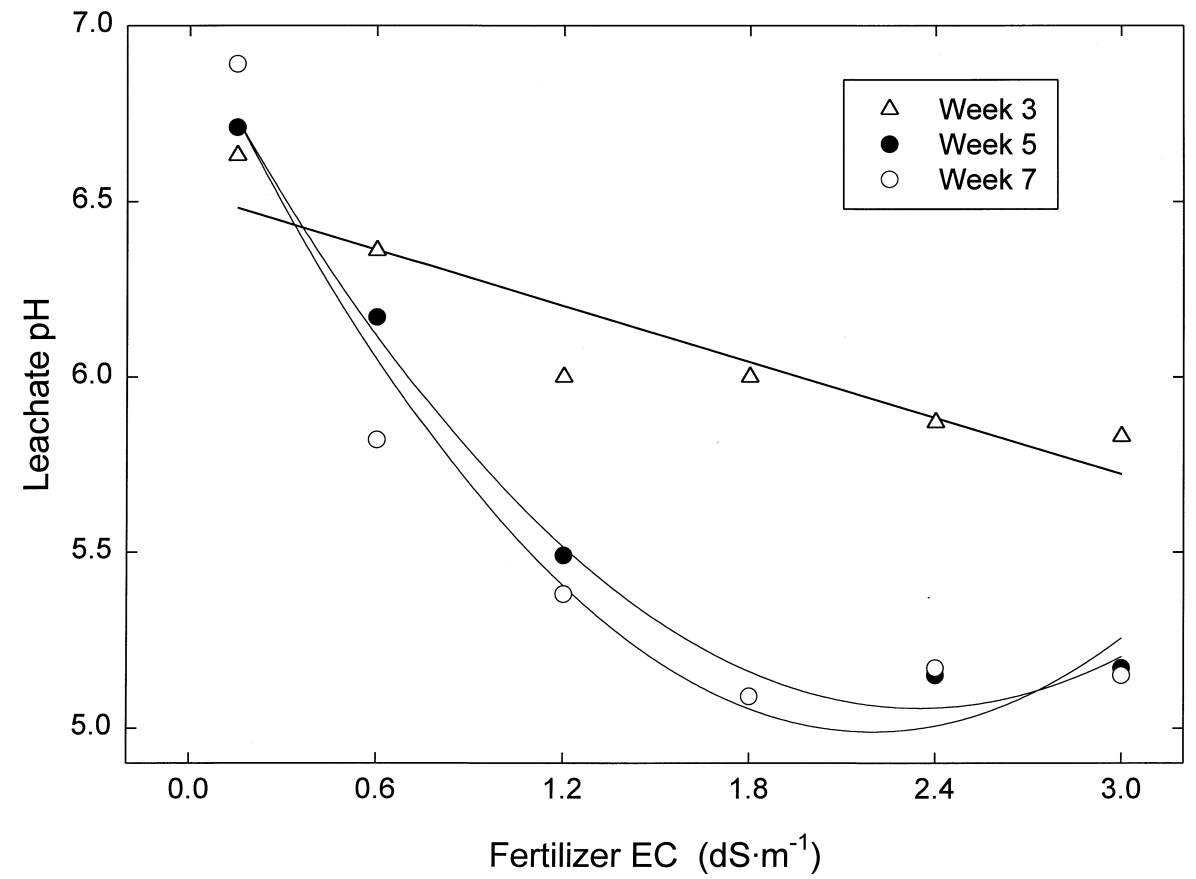

Fig. 4. The effect of fertilizer EC on the leachate $\mathrm{pH}$ of the soilless medium of begonias at 3,5, and 7 weeks after transplanting. There were no significant differences in leachate $\mathrm{pH}$ of different soilless media and data from the three media were averaged. Lines indicate significant linear or quadratic effects; $P \leq 0.05$ $(\mathrm{n}=12)$. 
Table 3. Regression coefficients of fertilizer EC vs. leachate EC of three different begonia growing media at three different sampling times. Data are presented in Fig. 3.

\begin{tabular}{lcccc}
\hline \hline Week & Medium & Intercept $\left(\mathrm{dS} \cdot \mathrm{m}^{-1}\right)$ & Slope & $r^{2}$ \\
\hline 3 & MM220 & $0.04 \mathrm{a}^{\mathrm{z}}$ & $1.51 \mathrm{a}$ & 0.99 \\
& MM366C & $-0.19 \mathrm{a}$ & $1.39 \mathrm{a}$ & 0.98 \\
& MM500 & $-0.02 \mathrm{a}$ & $1.10 \mathrm{~b}$ & 0.98 \\
& & & \\
5 & MM220 & $-0.78 \mathrm{a}$ & $3.27 \mathrm{a}$ & 0.98 \\
& MM366C & $-0.56 \mathrm{a}$ & $2.54 \mathrm{~b}$ & 0.90 \\
& MM500 & $-0.60 \mathrm{a}$ & $2.44 \mathrm{~b}$ & 0.85 \\
& & & & \\
7 & MM220 & $-1.46 \mathrm{a}$ & $4.05 \mathrm{a}$ & 0.93 \\
& MM366C & $-0.77 \mathrm{a}$ & $2.74 \mathrm{~b}$ & 0.87 \\
& MM500 & $-0.54 \mathrm{a}$ & $2.24 \mathrm{~b}$ & 0.96 \\
\hline
\end{tabular}

${ }^{\mathrm{z}}$ Separation within columns and weeks by homogeneity tests $(P \leq 0.05)$

\section{Literature Cited}

Argo, W.R. and J.A. Biernbaum. 1994. Irrigation requirements, root-medium $\mathrm{pH}$, and nutrient concentrations of Easter lilies grown in five peatbased media with and without an evaporative barrier. J. Amer. Soc. Hort. Sci. 119:1151-1156.

Blom, T.J. and B.D. Piott. 1992. Preplant moisture content and compaction of peatwool using two irrigation techniques on potted chrysanthemum. J. Amer. Soc. Hort. Sci. 117:220-223.

Bugbee, B. 1995. Nutrient management in recirculating hydroponic culture, p. 15-30. In: Proc. 16th Annu. Conf. Hydroponics. Hydroponic Soc. Amer., San Ramon, Calif.

Bunt, A.C. 1988. Media and mixes for containergrown plants. 2nd ed. Unwin Hyman, Boston, Mass.

Chase, A.R. and R.T. Poole. 1987. Effect of fertilizer rate on growth of fibrous-rooted begonia. HortScience 22:162.

de Kreij, C. and N. Straver. 1988. Flooded-bench irrigation: Effect of irrigation frequency and type of potting soil on growth of Codiaeum and on nutrient accumulation in the soil. Acta Hort. 221:245-252.

Dole, J.M., J.C. Cole, and S.L. von Broembsen. 1994 Growth of poinsettias, nutrient leaching, and wateruse efficiency respond to irrigation methods. HortScience 29:858-864.

Evans, M.R. and J.K. Iles. 1997. Growth of Viburnum dentatum and Syringa $\times$ prestoniae 'Donald Wyman' in Sphagnum peat and coir dust-based substrates. J. Environ. Hort. 15:156- 159.

Fonteno, W.C. and T.E. Bilderback. 1993. Impact of hydrogel on physical properties of coarse-structured horticultural substrates. J. Amer. Soc. Hort. Sci. 118:217-222.

Frett, J.J., M.A. Dirr, and A.M. Armitage. 1985. Nitrogen and calcium requirements of petunia hybrida 'Coral Sea'. Scientia Hort. 26:351-359.

Gislerød, H.R. and L.M. Mortensen. 1990. Relative humidity and nutrient uptake and growth of $\mathrm{Be}$ gonia $\times$ hiemalis. HortScience 25:524-526.

Joiner, J.N., R.T. Poole, and C.A. Conover. 1983. Nutrition and fertilization of ornamental greenhouse crops. Hort. Rev. 5:317-403.

Jones, J.B. and V.W. Case. 1990. Sampling, handling, and analyzing plant tissue samples, p. 389-427. In: R.L. Westerman (ed.). Soil testing and plant analysis. Soil Sci. Soc. Amer., Madison, Wis.

Kent, M.W. and D.W. Reed. 1996. Nitrogen nutrition of New Guinea impatiens 'Barbados' and Spathiphyllum 'Petite' in a subirrigation system. J. Amer. Soc. Hort. Sci. 121:816-819.

Lang, H.J. 1996. Growing media testing and interpretation, p. 123-139. In: D.W. Reed (ed.). Water, media, and nutrition for greenhouse crops. Ball Publishing, Batavia, Ill.

Lemaire, F., G. Sintès, and P. Morel. 1995. Mineral needs of Begonia $\times$ elatior during the growing period and the flowering time. Acta Hort. 396:219 226.

Mikkelsen, J. 1973. Simplified instructions for Rieger elatior begonia growth. Florists' Rev. 153 (3957):71-78

Mills, H.A. and J.B. Jones. 1996. Plant analysis handbook II. MicroMacro Publishing, Athens, $\mathrm{Ga}$.

Molitor, H.-D. 1990. The European perspective with emphasis on subirrigation and recirculation of water and nutrients. Acta Hort. 272:165170.

Morvant, J.K., J.M. Dole, and E. Allen. 1997. Irrigation systems alter distribution of roots, soluble salts, nitrogen, and $\mathrm{pH}$ in the root medium. HortTechnology 7:156-160.

Morvant, J.K., J.M. Dole, and J.C. Cole. 1998 Irrigation frequency and system affect poinsettia growth, water use, and runoff. HortScience 33:42-46

National Pesticide Survey. 1990. Summary results of EPA's national survey of pesticides in drinking water wells. EPA Office of Pesticides and Toxic Substances.

Nelson, P.V., D.M. Krauskopf, and N.C. Mingis. 1978. Nitrogen and potassium requirements of Rieger begonia (Begonia $\times$ hiemalis Fotsch). J. Amer. Soc. Hort. Sci. 103:603-605.

Poole, R.T. and C.A. Conover. 1992. Fertilizers and medium affect foliage plant growth in an ebb and flow irrigation system. J. Environ. Hort. 10:81-86.

Stamps, R.H. and M.R. Evans. 1997. Growth of Dieffenbachia maculata 'Camille' in growing media containing sphagnum peat or coconut coir dust. HortScience 32:844-847.

Uva, W.L., T.C. Weiler, and R.A. Milligan. 1998. A survey on the planning and adoption of zero runoff subirrigation systems in greenhouse operations. HortScience 33:193-196

van Iersel, M. 1999. Fertilizer concentration affects growth and nutrient composition of subirrigated pansies. HortScience 34:660-663.

van Iersel, M.W., R.B. Beverly, P.A. Thomas, J.G. Latimer, and H.A. Mills. 1998. Fertilizer effects on the growth of impatiens, petunia, salvia, and vinca plug seedlings. HortScience 33:678-682.

Warncke, D.D. 1986. Analyzing greenhouse growth media by the saturation extraction method. HortScience 21:223-225.

White, J.W., J. Holcomb, and T. Maczko. 1973 Rieger elatior begonia research at Penn State. Florists' Rev. 153 (3961):32-34

Witte, W.T. and T.J. Sheehan. 1974. Effects of media and fertility on growth and flowering of Rieger begonia. Proc. Fla. State Hort. Soc. 87:508-512.

Wright, R.D. 1986. The pour-through nutrient extraction procedure. HortScience 21:227-229.

Yelanich, M.V and J.A. Biernbaum. 1990. Effect of fertilizer concentration and method of application on media nutrient content, nitrogen runoff and growth of Euphorbia pulcherrima V-14 Glory. Acta Hort. 272:185-189. 